\title{
Risk Factors On Returns Of Closed-End Funds
}

Junesuh Yi, (Email: juyi@dongguk.edu), Dongguk University, South Korea

Moon K. Kim, Syracuse University

\begin{abstract}
Risk factors of closed-end funds may not be identical to those of common stocks due to the unique characteristics of closed-end funds whose share price is different from net asset value determined by underlying investment portfolios. This study investigates the relationship between closed-end fund returns and the risk factors measured from two types of assets, fund itself and its underlying portfolios. We also examine the size and the book-to-market effect of both two types of assets. This paper finds that size and book-to-market related factors measured from both fund itself and its investment portfolio play a significant role as risk factors, accounting for closed-end fund returns. These risk factors measured from fund itself are observed as equally important as those from investment portfolio characteristics. In addition, the book-to-market effect of fund itself assets is clearly showed.
\end{abstract}

\section{INTRODUCTION}

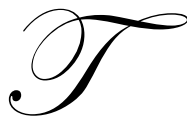

he appeal of closed-end funds to investors has increased in recent years. From 1986 to 2003, the number of closed-end funds rose from 69 to 586 while their assets increased more than ten times from $\$ 12$ billion to $\$ 213$ billion. ${ }^{1}$ Although investors determine the share price of the closed-end fund based on underlying assets included in its portfolio, the share price is often lower than the market share value of the portfolio, which is also known as the net asset value (NAV). Furthermore, the risk on fund price returns is not identical to the risk on investment portfolio returns. Pontiff (1997) shows that the variance of returns on the closedend fund price is much greater than the variance of returns on the net asset value. For open-end mutual funds, the share price of the fund is identical to the market value of the investment portfolio simply because there is no market price for a mutual fund. Thus, one important question for closed-end funds is which asset characteristics is more important to investors, the characteristics of the fund itself or the characteristics of securities held by portfolio of the fund.

Fama and French $(1992,1993,1996)$ three factor model has been employed as one of the remarkable asset pricing models in academics. Of closed-end funds studies, Pontiff (1995) uses Fama and French's three-factor model to explain the premium of closed-end fund price over the portfolio price (or net asset value). Pontiff (1995) uses these risk factors derived from common stocks, but does not consider risk factors derived from fund itself or its underlying portfolio characteristics. Risk factors of closed-end funds may not be identical to those of common stocks due to the unique characteristics of closed-end funds whose share price is different from net asset value determined by underlying investment portfolios. For example, a small fund may invest in large firms and vice versa. The same analogy can be made for the market return and book-to-market equity ratio risk factors. Closed-end funds are unique in the sense that risk characteristics of the fund itself and its underlying investment portfolio can be different from each other in terms of the three risk factors. Thus, it is an important issue to investigate which risk characteristics is more important to investors, those independently drawn from closed-end fund itself or investment portfolio characteristics or both. For this purpose, this study develops an ad hoc Fama-French three factor model that return

\footnotetext{
${ }^{1}$ Mutual Fund Fact Book, 2004 ed., Investment Company Institute.
} 
series of SMB and HML are calculated not on stock returns but on closed-end fund returns of mimicking portfolio constructing, based on size and book-to-market ratio of fund itself and its underlying investment stocks. ${ }^{2}$

In addition, we examine whether the returns of close-end funds show the market anomalies such as size or book-to-market effect with respect to fund itself as well as its underlying portfolio through a cross-sectional test. Empirical evidence on the size effect on mutual funds is mixed. Grinblatt and Titman (1989) find that small mutual funds perform slightly better than large mutual funds. Gorman (1991) reexamines this result to show that net total return has a negatively weak relationship with fund size, but Philpot, et al. (1998) find that the return is positively related to the fund size of bond mutual funds. With regard to the size effect of closed-end funds, Lee, Sheifer, and Thaler (1991) find that changes in closed-end fund returns are correlated with firm size.

On the other hand, the book-to-market equity effect is significant in mutual fund returns. Rosenberg, Reid, and Lanstein (1985) find a positive relationship between average return and the book-to-market equity ratio of US stocks. Chan, Hamao and Lakonishok (1991) show that the book-to-market value ratio is a powerful variable for explaining average returns on Japanese stocks. Lakonishok, Shleifer, and Vishny (1994) assume that low book-tomarket equity stocks have low average returns because future earnings growth is weaker than the market expectations. Previous studies, however, only used the closed-end fund firm characteristics without considering the likelihood of different characteristics of stocks held by portfolios.

The purpose of this paper is to investigate how closed-end fund returns are related to risk factors, measured from closed-end fund itself and from investment portfolio of the fund. This paper also examines the size effect and the book-to-market effect as to fund itself as well as its underlying portfolio. So far, we have not seen any empirical research for analyzing these two types of risk factors in the valuation of closed-end funds.

Section 2 and 3 describe the methodology and data used in this study. We examine such risk factors as market return, size, and book-to-market equity factors measured from both fund itself and its underlying investment portfolios and how these risk measures are related to risk premiums of closed-end funds. Section 4 presents the results of empirical tests regarding the size or the book-to-market effect and the relationship between returns and risk factors of fund itself and investment portfolios. Finally, Section 5 presents conclusions.

\section{METHODOLOGY}

To investigate the size effect and the book-to-market effect for closed-end funds, we first examine average returns for portfolios of closed-end funds established using the asset size and book-to-market equity ratio of both fund itself and its underlying investment portfolios. We also conduct a cross-sectional regression of closed-end fund returns on size and book-to-market values of both types of assets. In addition, we perform time-series regressions of fund returns on risk factors.

\section{Average Portfolio Returns}

The average return matrix provides average returns on portfolios of closed-end funds stratified by asset size and book-to-market equity ratio. Sample closed-end funds are assigned to three market equity (ME) size portfolios (small, medium, and big) using (i) fund size and (ii) median market capitalization (MMC) of firms included in investment portfolio, respectively, at the beginning of year $\mathrm{t}$. Then, funds included in size portfolios are divided into three book-to-market (BM) equity ratio portfolios (low, medium, and high). Thus, nine portfolios are established for funds themselves and investment portfolios, respectively. The BM equity ratio of assets is defined as the net asset value (NAV) divided by the share price while that of investment assets is the average book-to-market equity ratio of securities included in investment assets. The average return of each portfolio is the time series average of monthly returns.

\footnotetext{
${ }^{2}$ If we use SMB and HML series of Fama and French, the investigation of separation effect of fund assets and investment assets do not make sense because SMB and HML series of two assets are identical.
} 


\section{Cross-Sectional Regressions}

To investigate on the existence of market anomalies of closed-end funds returns, we conduct a cross-section approach using the size and the book-to-market value of fund itself and its underlying investment portfolio. As suggested in Fama and French (1992), cross-sectional regression models for both fund assets and underlying portfolio assets are designed as follows.

$$
\begin{aligned}
& R_{j t}=a_{j}+b_{j} \beta_{j t}+s_{j} \ln \left(M E F_{j t}\right)+h_{j} \ln \left(B M F_{j t}\right)+e_{j t} \\
& R_{j t}=a_{j}+b_{j} \beta_{j t}+s_{j} \ln \left(M E I_{j t}\right)+h_{j} \ln \left(B M I_{j t}\right)+e_{j t}
\end{aligned}
$$

where $R_{j t}=$ the monthly stock return of fund $\mathrm{j}$ in time period $\mathrm{t}$ including dividends and capital gains distributions, $\beta_{j t}=$ the sensitivity of fund j's return to the benchmark(S\&P 500) during 36 months prior to t, $M E F_{j t}=$ market equity of fund $\mathrm{j}$. (NAV), $B M F_{j t}=$ book to market value ratio of fund $\mathrm{j}, M E I_{j t}=$ market medium capitalization $(\mathrm{MMC})$ for underlying investment assets, and $B M I_{j t}=$ book-to-market value ratio of fund $\mathrm{j}$ for underlying investment assets. The period of closed-end fund returns ranges from one to twelve months prior to $\mathrm{ME}$ or to $\mathrm{BE} / \mathrm{ME}$, and the cross-sectional regression is executed for 84 months because fund returns is computed by month.

\section{Time-Series Regressions}

Fama and French $(1993,1996)$ argue that excess market return, SMB (return difference between small stock and big stock portfolios), and HML (return difference between high and low book-to-market equity portfolios) capture the common risk factors for explaining the average stock returns. We examine that these three factors can play a role as risk factors in closed-end funds. Due to the unique characteristics of closed-end funds whose share price is different from net asset value determined by underlying investment portfolios, we use return series of SMB and HML calculated not on stock return but on closed-end fund returns, in identifying size and book-to-market ratio of both fund itself and its underlying investment portfolio. In other words, we employ the ad hoc Fama-French three factor model postulating that risk factors computed by closed-end fund returns play a role identical to those by stock returns.

Since our interest in this study is in contrasting risk characteristics of fund themselves versus their investment portfolios, we directly obtain return series of portfolios established based on size and BM factors. First, closed-end funds is split into three groups based on size: small, medium, and big as of July of year $t$, and then each group is again divided into three groups based on book-to-market ratio as of December of year $t-1$. Monthly equal weighted returns on nine portfolios (three size classes $\times$ three BM classes) are computed from July of year $t$ to June of $t+1$, and the portfolios are reorganized in June of $t+1$. From nine portfolios, the return difference between small and big closed-end fund portfolios classified by size is an independent variable called "SMB". Also, the return difference between high and low closed-end fund portfolios classified by book-to-market ratio is another variable called "HML". Finally, the excess market return of the S\&P 500 index over the risk-free rate is the market return factor. The time series regression models for funds themselves and their investment portfolios can be written as

$$
\begin{aligned}
& R_{j t}-R F_{t}=a_{j}+b_{j}\left(R M_{t}-R F_{t}\right)+s_{j} S M B F_{t}+h_{j} H M L F_{t}+e_{1 t} \\
& R_{j t}-R F_{t}=a_{j}+b_{j}\left(R M_{t}-R F_{t}\right)+s_{j} S M B I_{t}+h_{j} H M L I_{t}+e_{2 t}
\end{aligned}
$$

where $R F_{t}=$ the risk free rate as measured by three-month T-bill rate, $R M_{t}=$ the market return as measured by S\&P $500, S M B F_{t}=$ the return difference between small and big portfolios classified by the size(market equity) of fund assets, $H M L F_{t}=$ the return difference between high and low portfolios classified by the book-to-market value ratio 
of fund assets, $S M B I_{t}=$ the return difference between small and big portfolios classified by the size (MMC) of securities included in investment portfolios, and $H M L I_{t}=$ the return difference between high and low portfolios classified by the book-to-market equity ratio of investment portfolios.

\section{DATA}

Sample closed-end funds are selected during the 1993-1999 period. The selection criteria are: (i) closed-end funds should be covered in the Wall Street Journal during the study period, (ii) only equity funds are selected because bond funds do not provide size or book-to-market equity ratio data, and (iii) the closed-end funds have operating data, including NAV and premium (or discount) of closed-end funds, and the average book-to-market equity ratio and MMC of funds included in the portfolio. We found 103 closed-end funds consisting of 37 domestic equity funds and 66 foreign stock funds. Among 103 funds, 82 funds existed as of December 1999 (see the Appendix for the list of sample funds.) Fund characteristics are measured at the beginning of each year but monthly returns are obtained from July of each year to June of the following year. This is to take into account the time needed to have full disclosure of information on fund operations (Fama and French (1992 and 1993)). If a fund has stock return data from July of year $t$ through June of year $t+1$, then its year-begin size and book-to-market equity ratio are collected for year $t$.

Return and price data were obtained from The Center for Research in Security Prices (CRSP) files and Yahoo Finance. The net asset value and other data related to portfolio assets were obtained from the Morningstar Mutual Fund (1996, 1997, and 1998), the Morningstar Closed-End Funds 250 (1994 and 1995), and the Morningstar Closed-End Funds (1992 and 1993). Since some funds included in the sample went out of business during the study period and Morningstar does not give closed-end funds data on a consistent basis, the number of sample funds is different from year to year. Since we collect all available closed-end funds during the study period, survival bias would be minimal, if any, in this study. In the final sample, there are 20 funds in 1993, 56 in 1994, 78 in 1995, 76 in 1996, 72 in 1997, 55 in 1998, and 53 in 1999.

\section{EMPIRICAL RESULTS}

\section{Average Returns}

Table 1 shows average returns on portfolios formed using three sizes (small, medium, and big) and three BM classes (low, medium, and high) for both funds themselves and their investment portfolios. We can observe the size effect by reading the table by column and the book-to-market effect by row.

For funds themselves, we observe rather weak size effect, if any. Small size portfolios sometimes have larger excess returns than medium or big size portfolios, but not on a consistent basis. On the other hand, the BM equity effect is clearly shown. The higher the BM equity ratio, the larger the excess returns.

For investment portfolios of the funds, both the size and BM ratio effects are rather weak. The smaller size portfolio tends to have higher returns and the high BM ratio portfolio tends to have higher returns than low and medium BM ratio portfolios.

In summary, the analysis of average portfolio returns shows that the book-to-market effect is strongly present for funds assets but the size effect is marginally present. The size and BM ratio effects are marginally present in investment portfolios of funds. 
Table 1

Average Monthly Returns (\%) On Portfolios Formed On Size And Book-To-Market Equity: July 1993 To June 2000

\begin{abstract}
At the beginning of each year $t$, the sample funds are assigned into three size portfolios using the size of fund assets and the average firm size of investment assets. Then, the sample funds in each size are then divided into three book-to-market portfolios of fund assets and investment assets. Then, monthly returns are collected for the portfolio from July of year $t$ through June of year $t+1$. Average monthly return is the time-series average of monthly portfolio returns.
\end{abstract}

\begin{tabular}{|c|c|c|c|c|}
\hline \multicolumn{5}{|c|}{ Fund Assets } \\
\hline \multirow{2}{*}{ Size } & \multicolumn{4}{|c|}{ Book-to-Market Equity } \\
\hline & All & Low & Med & High \\
\hline All & 0.71 & 0.02 & 0.83 & 1.29 \\
\hline Small & 0.74 & -0.27 & 1.20 & 1.30 \\
\hline Med & 0.63 & 0.26 & 0.44 & 1.19 \\
\hline Big & 0.76 & 0.07 & 0.86 & 1.37 \\
\hline \multicolumn{5}{|c|}{ Investment Assets } \\
\hline \multirow{2}{*}{ Size } & \multicolumn{4}{|c|}{ Book-to-Market Equity } \\
\hline & All & Low & Med & High \\
\hline All & 0.70 & 0.75 & 0.54 & 0.81 \\
\hline Small & 0.84 & 0.90 & 0.25 & 1.36 \\
\hline Med & 0.44 & 0.40 & 0.42 & 0.52 \\
\hline Big & 0.81 & 0.94 & 0.95 & 0.54 \\
\hline
\end{tabular}

\title{
Cross-Sectional Regression Analysis
}

Not surprisingly, only the book-to-market effect of fund assets is obviously observed. Table 2 presents evidence that there is significant and positive relationship between closed-end fund returns and book-to-market ratio of fund assets. The other market anomalies (size effect of fund assets and investment assets, and book-to-market effect of investment assets) are not clearly found.

The sign on coefficients of book-to-market ratio of investment assets also turns out to be positive but statistically insignificant. It suggests that the characteristics of underlying portfolio assets less affects the closed-end fund returns than those of investment assets. The size effects of both fund assets and investment assets are not shown. These findings are consistent with empirical evidences of mutual fund studies that there exist the mixed results of size effect. 
Table 2

Cross Sectional Regressions Of Stock Returns On Beta, Size And Book-To-Market Equity For Fund Assets And Its Underlying Investment Portfolio Assets

$$
\begin{aligned}
& R_{j t}=a_{j}+b_{j} \beta_{j t}+s_{j} \ln \left(M E F_{j t}\right)+h_{j} \ln \left(B M F_{j t}\right)+e_{j t} \\
& R_{j t}=a_{j}+b_{j} \beta_{j t}+s_{j} \ln \left(M E I_{j t}\right)+h_{j} \ln \left(B M I_{j t}\right)+e_{j t}
\end{aligned}
$$

\begin{tabular}{|c|c|c|c|c|c|c|c|}
\hline \multicolumn{4}{|c|}{ Fund Assets } & \multicolumn{4}{|c|}{ Investment Assets } \\
\hline & Mean & Std.Dev. & $t$ & & Mean & Std.Dev. & $t$ \\
\hline$a_{j}$ & 1.13 & 7.80 & 1.33 & $a_{j}$ & 1.01 & 3.68 & 0.73 \\
\hline$b_{j}$ & -0.60 & 4.83 & -1.15 & $b_{j}$ & -0.28 & 2.58 & -0.99 \\
\hline$s_{j}$ & -0.07 & 0.94 & -0.64 & $s_{j}$ & -0.03 & 0.41 & -0.19 \\
\hline$h_{j}$ & 4.49 & 13.31 & 3.10 & $h_{j}$ & 0.53 & 0.99 & 1.41 \\
\hline
\end{tabular}

Mean is the time series mean of a monthly return. Std.Dev. is the time-series standard deviation. $\mathrm{t}$ is t-values.

\section{Time Series Regression Analysis}

The descriptive statistics of the variables used in time-series regressions are presented in Table 3 . The average excess market return (RM-RF) over the sample period is 1.33 percent per month. It is interesting to note that SMBF is highly correlated with SMBI (0.73) while HMLF is not with HMLI (0.12). It implies that a small fund is more likely to invest in small firms whereas a fund is less likely to consider the book-to-market ratio of invested firms. The results of time-series regressions of (2a) and (2b) are shown in Table 4.

Table 3

\section{Descriptive Statistics of The Variables Used In Time-Series Regressions}

Summary statistics are for the return series of monthly dependent and independent variables (in percent).

\begin{tabular}{|c|c|c|c|c|c|c|c|}
\hline & \multicolumn{5}{|c|}{ Correlation Coefficients } & \multirow[t]{2}{*}{ Mean } & \multirow[t]{2}{*}{ Std. Dev. } \\
\hline & RF & SMBF & HMLF & SMBI & HMLI & & \\
\hline $\mathrm{RM}$ & 0.13 & 0.34 & 0.14 & 0.30 & 0.17 & 1.73 & 3.91 \\
\hline RF & 1 & -0.04 & 0.11 & -0.10 & -0.12 & 0.40 & 0.06 \\
\hline SMBF & & 1 & 0.51 & 0.73 & 0.25 & -0.06 & 7.92 \\
\hline HMLF & & & 1 & 0.24 & 0.12 & 3.80 & 9.43 \\
\hline SMBI & & & & 1 & 0.39 & 0.09 & 8.49 \\
\hline HMLI & & & & & 1 & 0.18 & 8.23 \\
\hline
\end{tabular}

Data cover 84 months from July 1993 to June 2000.

$\mathrm{RF}$ is the risk free rate using three-month T-bill rate, RM is the market return using S\&P 500, SMBF is the return difference between small and big portfolios classified by size (NAV) of fund assets, and HMLF is the return difference between high and low portfolios classified by the book-to-market ratio (premium/discount) of fund assets, SMBI is the return difference between small and big portfolios classified by the firm size of investment assets (MMC), and HMLI is the return difference between high and low portfolios classified by the book-to-market equity ratio of investment assets. 
Table 4

Time-Series Regressions Of The Excess Stock Return On The Excess Market Return, The Return Difference Of The Size Portfolio (SMB), And The Return Difference Of The Book-To-Market Equity Portfolio (HML) For The Period From July 1993 To June 2000

$$
\begin{gathered}
R_{j t}-R F_{t}=a_{j}+b_{j}\left(R M_{t}-R F_{t}\right)+s_{j} S M B F_{t}+h_{j} H M L F_{t}+e_{1 t} \\
R_{j t}-R F_{t}=a_{j}+b_{j}\left(R M_{t}-R F_{t}\right)+s_{j} S M B I_{t}+h_{j} H M L I_{t}+e_{2 t}
\end{gathered}
$$

\begin{tabular}{|c|c|c|c|c|c|c|c|}
\hline \multicolumn{4}{|c|}{ Fund Assets } & \multicolumn{4}{|c|}{ Investment Assets } \\
\hline $\mathbf{a}_{\mathbf{j}}$ & Low & Med & High & $\mathbf{a}_{\mathbf{j}}$ & Low & Med & High \\
\hline Small & $-0.81^{*}$ & -0.35 & -0.57 & Small & -0.52 & $-1.27^{* * * *}$ & -0.14 \\
\hline Med & -0.02 & $-1.06^{* *}$ & -0.57 & Med & $-1.08^{* * *}$ & $-1.14^{* * *}$ & $-0.98^{* *}$ \\
\hline Big & $-0.70^{*}$ & $-0.65^{*}$ & -0.38 & Big & -0.49 & -0.48 & $-0.96^{* * *}$ \\
\hline $\mathbf{b}_{\mathbf{j}}$ & Low & Med & High & $\mathbf{b}_{\mathbf{j}}$ & Low & Med & High \\
\hline Small & $0.83^{* * *}$ & $0.77^{* * *}$ & $0.73^{* * * *}$ & Small & $0.77^{* * *}$ & $0.82^{* * * *}$ & $0.77^{* * *}$ \\
\hline Med & $0.90^{* * * *}$ & $0.85^{* * *}$ & $0.81^{* * * *}$ & Med & $0.80^{* * *}$ & $0.85^{* * *}$ & $0.79^{* * *}$ \\
\hline Big & $0.64^{* * *}$ & $0.85^{* * *}$ & $0.84^{* * * *}$ & Big & $0.79^{* * * *}$ & $0.77^{* * * *}$ & $0.80^{* * *}$ \\
\hline $\mathbf{S}_{\mathbf{j}}$ & Low & Med & High & $\mathbf{S}_{\mathbf{i}}$ & Low & Med & High \\
\hline Small & $0.30^{* * *}$ & $0.30^{* * * *}$ & $0.32^{* * * *}$ & Small & $0.45^{* * *}$ & $0.28^{* * * *}$ & $0.35^{* * *}$ \\
\hline Med & $0.28^{* * * *}$ & $0.24^{* * *}$ & $0.32^{* * * *}$ & Med & $0.18^{* * * *}$ & $0.19^{* * * *}$ & $0.24^{* * *}$ \\
\hline Big & -0.01 & -0.00 & 0.02 & Big & 0.03 & -0.02 & $0.06^{* *}$ \\
\hline $\mathbf{h}_{\mathbf{j}}$ & Low & Med & High & $\mathbf{h}_{\mathbf{j}}$ & Low & Med & High \\
\hline Small & $-0.25^{* * *}$ & 0.04 & $0.14^{* * * *}$ & Small & $-0.26^{* * *}$ & 0.03 & $0.29^{* * *}$ \\
\hline Med & $-0.34^{* * * *}$ & -0.00 & 0.08 & Med & -0.04 & 0.08 & $0.13^{* *}$ \\
\hline Big & $-0.13^{* * *}$ & -0.00 & 0.06 & Big & $-0.11^{* * *}$ & 0.01 & $0.17^{* * *}$ \\
\hline Adj-R ${ }^{2}$ & Low & Med & High & Adj- $R^{2}$ & Low & Med & High \\
\hline Small & 0.63 & 0.58 & 0.69 & Small & 0.77 & 0.62 & 0.74 \\
\hline Med & 0.58 & 0.56 & 0.62 & Med & 0.41 & 0.60 & 0.60 \\
\hline Big & 0.38 & 0.53 & 0.47 & Big & 0.49 & 0.42 & 0.62 \\
\hline
\end{tabular}

***Significant at the 1 percent level

**Significant at the 5 percent level

*Significant at the 10 percent level

The mean adjusted $\mathrm{R}^{2}$ values are 0.56 and 0.59 for fund and investment assets, respectively.

SMB, the size related factor, and HML, the book-to-market related factor, of both fund themselves and their investment portfolios are found to play a role as risk factors in explaining closed-end fund returns. The coefficients for SMBF and SMBI decrease as the asset size increases, and the coefficients for HMLF and HMLI increase as the BM size increases for both funds themselves and their investment portfolios. In other words, the coefficients of SMBF and SMBI of small size are all greater than those of big size, and the coefficients of HMLF and HMLI of high BM equity ratio are all greater than those of low BM equity ratio for both funds and their investment portfolios. 
All of the market beta coefficients of each portfolio, $b_{j}$, are statistically significant, suggesting that excess market return is also one of the risk factors to account for closed-end fund returns. ${ }^{3}$ Most adjusted $\mathrm{R}^{2}$ values are higher than 0.50. It implies that these models are not completely perfect to capture other risk factors, but deserve to be accepted. Moreover, the smaller size and higher BM portfolios tend to have higher $\mathrm{R}^{2}$ values.

The overall results are very similar to each other when the return-risk relationship for funds themselves is compared with that for their investment portfolios. Thus, it leads to the conclusion that the three-risk factor model derived from both funds themselves and their investment portfolios explain the returns of closed-end funds.

\section{Time-Series Regressions With Both Fund Itself And Its Investment Portfolio Variables}

In the previous sections, we examined the return-risk relations independently for both closed-end funds themselves and their investment portfolios. In this section the risk factors for both funds and investment portfolios are jointly considered in a time-series regression model. In the results presented in the previous sections, it may be possible that a fund belonging to a small size fund group belongs to a large size investment portfolio group. In this case, the fund earning a larger premium due to a small size factor may earn a smaller premium due to the fact that its investment portfolio asset size is large. In other words, if the two asset characteristics of a fund fall into two different categories, the size effect of fund assets cannot be estimated correctly due to the existence of the size effect of investment portfolios or vice versa. Therefore, poor results may be obtained in the individual regressions of (2a) and (2b). To adjust for this cross effect, equations (2a) and (2b) for both assets are combined:

$$
\begin{aligned}
R_{j t}-R F_{t}=a_{j}+b_{j} & \left(R M_{t}-R F_{t}\right)+s_{j F} S M B F_{t}+h_{j F} H M L F_{t} \\
+ & s_{j I} S M B I_{t}+h_{j I} H M L I_{t}+e_{3 t}
\end{aligned}
$$

The testing procedure is identical to the one used in the previous time-series regressions. Since there is no sufficiently large number of sample funds to use to establish portfolios stratified by four classes (the size and the BM ratio of both fund itself and its investment portfolio), we utilize the nine fund portfolios and the nine investment portfolios which were used in testing equation (2). The first of the nine fund portfolios is combined with the first of the nine investment portfolios using equal weights. Thus, the resulting portfolio includes the characteristics of the first fund portfolio as well as those of the corresponding investment portfolio. We repeat this procedure for the remaining eight portfolios. Each of the resulting nine portfolios will have similar fund and investment asset characteristics, i.e., if a portfolio includes small size-low BE fund companies, it also includes small size-low BE investment portfolios.

The results of regressions of equation (3) for the nine portfolios are shown in Table 5. First, the size-related risk factors both for funds themselves $\left(s_{j F}\right)$ and for investment portfolios $\left(s_{j I}\right)$ are clearly present. As the fund

${ }^{3}$ The market beta coefficients, $b_{\mathrm{j}}$, are relatively low. But when excess returns are regressed on only excess market returns, the market beta coefficients increase substantially upward and some are greater than one. The regression coefficients, $b_{\mathrm{j}}$, estimated from $R_{j t}-R F_{t}=a_{j}+b_{j}\left(R M_{t}-R F_{t}\right)+e_{j}$ for fund assets are:

\begin{tabular}{|l|l|l|l|}
\hline & Low & Med & High \\
\hline Small & 1.02 & 0.99 & 1.00 \\
\hline Med & 0.98 & 1.01 & 1.06 \\
\hline Big & 0.60 & 0.84 & 0.88 \\
\hline
\end{tabular}

And the regression coefficients, $b_{\mathrm{j}}$, for investment assets are:

\begin{tabular}{|l|l|l|l|}
\hline & Low & Med & High \\
\hline Small & 0.97 & 1.01 & 1.10 \\
\hline Med & 0.91 & 1.00 & 1.00 \\
\hline Big & 0.77 & 0.76 & 0.90 \\
\hline
\end{tabular}


itself size increases and the average size of funds included in the portfolio increases, the coefficients for SMBF and SMBI become smaller. Also, the risk factors associated with book-to-market market equity ratio $\left(h_{j F}\right.$ and $\left.h_{j I}\right)$ for funds themselves and their investment portfolios are also found. As the BM ratio increases, the coefficient for HML becomes larger. The coefficients estimated jointly are, in general, smaller than those estimated individually for funds themselves and their investment portfolios. The average $\mathrm{R}^{2}$ slightly increases rather than those with fund assets only or investment assets only.

Table 5

Combined Time-Series Regressions Of The Excess Stock Return On The Excess Market Return, The Return Difference Of The Size Portfolio (SMB), And The Return Difference Of The Book-To-Market Equity Portfolio (HML) For The Period From July 1993 To June 2000

\begin{tabular}{|c|c|c|c|}
\hline \multicolumn{4}{|c|}{ Combined Assets } \\
\hline $\mathbf{a}_{\mathbf{j}}$ & Low & Med & High \\
\hline Small & $-0.73^{*}$ & -0.68 & -0.44 \\
\hline Med & -0.44 & $-1.17^{* * *}$ & -0.70 \\
\hline Big & -0.60 & -0.62 & -0.63 \\
\hline $\mathbf{b}_{\mathbf{j}}$ & Low & Med & High \\
\hline Small & $0.78^{* * *}$ & $0.77^{* * *}$ & $0.73^{* * * * *}$ \\
\hline Med & $0.85^{* * *}$ & $0.83^{* * *}$ & $0.78^{* * *}$ \\
\hline Big & $0.69^{* * *}$ & $0.79^{* * *}$ & $0.81^{* * * *}$ \\
\hline $\mathbf{s}_{\mathrm{iF}}$ & Low & Med & High \\
\hline Small & $0.17^{* *}$ & $0.14^{*}$ & 0.08 \\
\hline Med & 0.07 & 0.10 & 0.10 \\
\hline Big & -0.06 & -0.06 & 0.00 \\
\hline $\mathbf{h}_{\mathrm{iF}}$ & Low & Med & High \\
\hline Small & $-0.10^{* *}$ & -0.01 & $0.09^{* * *}$ \\
\hline Med & $-0.20^{* * *}$ & 0.02 & 0.03 \\
\hline Big & -0.06 & -0.02 & 0.02 \\
\hline $\mathbf{s}_{\mathbf{i I}}$ & Low & Med & High \\
\hline Small & $0.28^{* * * *}$ & $0.16^{* *}$ & $0.28^{* * * *}$ \\
\hline Med & $0.16^{* *}$ & $0.15^{* *}$ & $0.22^{* * *}$ \\
\hline Big & $0.10^{*}$ & 0.07 & 0.05 \\
\hline $\mathbf{h}_{\mathbf{j I}}$ & Low & Med & High \\
\hline Small & $-0.15^{* * *}$ & $0.10^{* *}$ & $0.14^{* * * *}$ \\
\hline Med & 0.05 & 0.02 & $0.08^{*}$ \\
\hline Big & -0.04 & 0.01 & $0.13^{* * * *}$ \\
\hline Adj-R & Low & Med & High \\
\hline Small & 0.73 & 0.67 & 0.75 \\
\hline Med & 0.53 & 0.63 & 0.66 \\
\hline Big & 0.48 & 0.52 & 0.57 \\
\hline
\end{tabular}

***Significant at the 1 percent level

**Significant at the 5 percent level

*Significant at the 10 percent level 


\section{CONCLUSIONS}

In this study we examine market anomalies of closed-end funds such as size or book-to-market effect as to two types of assets - fund itself and its underlying portfolio. Moreover, we investigate whether closed-end fund returns are related to risk factors, observed from fund itself characteristics or from its investment portfolio characteristics of closed-end funds.

As the result of this study, we find that there clearly exists the book-to-market effect of fund itself assets. The results also indicate that the size and the book-to-market related factors measured from both fund itself and its investment portfolio play a significant role as risk factors in accounting for closed-end fund returns. Finally, we find that the risk factors measured from fund itself characteristics are as strongly related to fund returns as the risk factors measured from investment portfolio characteristics. This result implies that closed-end fund investors need to observe not only fund itself risk characteristics but also portfolio risk characteristics to win the game.

\section{REFERENCES}

1. Bers, Martina K. and Jeff Madura, The performance persistence of closed-end funds, The Financial Review, Vol. 35, pp. 33-52, 2000.

2. Chan, Lois K., Yasushi Hamao, and Josef Lakonishok, Fundamentals and stock returns in Japan, Journal of Finance, Vol. 46, pp. 1739-1789.

3. Fama, Eugene F. and Kenneth R. French, The cross-section of expected stock returns, Journal of Finance, Vol. 47, pp. 427-465, 1992.

4. Fama, Eugene F. and Kenneth R. French, Common risk factors in the returns on stocks and bonds, Journal of Financial Economics, Vol. 33, pp. 3-56, 1993.

5. Fama, Eugene F. and Kenneth R. French, Multifactor explanations of assets pricing anomalies, Journal of Finance, Vol. 51, pp. 55-83, 1996.

6. Gorman, L, A study of the relationship between mutual fund return and asset size 1974-1987, Akron Business and Economic Review, Vol. 22, pp. 53-61. 1991.

7. Grinblatt, Mark and Sheridan Titman, An Analysis of Quarterly Portfolio Holdings, Journal of Business, Vol. 62, pp. 393-416, 1989

8. Lakonishock, Josef, Andrei Shleifer, and Robert W. Vishny, Contrarian investment, extrapolation, and risk, Journal of Finance, Vol. 49, pp. 1541-1578, 1994.

9. Lee, Charles M.C., Andrei Shleifer, and Richard H. Thaler, Investor sentiment and the closed-end fund puzzle, Journal of Finance, Vol. 46, pp. 76-110, 1991.

10. Philpot, James, Douglas Hearth, James N, Rimbey, and Craig T. Schulman, Active management, fund size, and bond mutual fund returns, The Financial Review, Vol. 33, pp. 115-126, 1998.

11. Pontiff, Jeffrey, Closed-end fund premia and returns implications for financial market equilibrium, Journal of Financial Economics, Vol. 37, pp. 341-370, 1995.

12. Pontiff, Jeffrey, Costly arbitrage: Evidence from closed-end funds, Quarterly Journal of Economics, Vol. 111, pp. 1135-1151, 1996.

13. Pontiff, Jeffrey, Excess volatility and closed-end funds, American Economic Review, 1997 March, pp. 155$168,1997$.

14. Rogenberg Barr, Kenneth Reid, and Ronald Lanstein, Persuasive evidence of market inefficiency, Journal of Portfolio Management, Vol. 11, pp. 9-17, 1985. 


\section{APPENDIX}

\section{List Of Closed-End Funds}

\begin{tabular}{|c|c|c|c|c|}
\hline Fund Ticker & Fund Name & Period $^{1}$ & Type $^{2}$ & Existence $^{3}$ \\
\hline $\mathrm{ADX}$ & Adams Express & & Domestic & Yes \\
\hline BZF & Brazil Fund & $95-99$ & Foreign & Yes \\
\hline CEE & Central European Equity & $96,98-99$ & Foreign & Yes \\
\hline CET & Central Securities & 93-99 & Domestic & Yes \\
\hline $\mathrm{CH}$ & Chile Fund & $95-98$ & Foreign & Yes \\
\hline CHN & China Fund & 94-96, 98-99 & Foreign & Yes \\
\hline CLM & Clemente Global Growth & $94-96$ & Foreign & Yes \\
\hline CRF & Central European Value & $98-99$ & Foreign & Yes \\
\hline CTF & Counsellors Tandem Securities & $93-95$ & Domestic & No \\
\hline DDF & Delaware Group Dividend \&Inc & $95-99$ & Domestic & Yes \\
\hline DNP & Duff \& Phelps Utilities Income & $95-99$ & Domestic & Yes \\
\hline $\mathrm{EF}$ & Europe Fund & $94-99$ & Foreign & Yes \\
\hline EGX & Engex & $93-96$ & Domestic & Yes \\
\hline EMF & Templeton Emerging Market & $93-99$ & Foreign & Yes \\
\hline EMO & TCW/DW Emerging Market Opp. & $96-97$ & Foreign & No \\
\hline EMG & Emerging Market Infrastructure & 95-98 & Foreign & No \\
\hline EQS & Equus II & $96-99$ & Domestic & Yes \\
\hline ETF & Emerging Markets Telecomm. & $95-99$ & Foreign & Yes \\
\hline $\mathrm{FF}$ & First Financial & 93-99 & Domestic & Yes \\
\hline FPF & First Philippine & $95-98$ & Foreign & Yes \\
\hline FRG & Emerging Germany & $94-96$ & Foreign & No \\
\hline FRF & France Growth & $94-98$ & Foreign & Yes \\
\hline FUND & America's All Season & $93,95-96$ & Foreign & Yes \\
\hline GAB & Gabelli Equity & 93-99 & Domestic & Yes \\
\hline GAM & General American Investors & $93-99$ & Domestic & Yes \\
\hline $\mathrm{GCH}$ & Greater China & $95-99$ & Foreign & Yes \\
\hline GER & Germany Fund & $94-99$ & Foreign & Yes \\
\hline GF & New Germany & 94-99 & Foreign & Yes \\
\hline GHS & Invesco Global Health Sciences & $94-99$ & Domestic & Yes \\
\hline GMI & Gemini II Capital & $93-96$ & Domestic & No \\
\hline GRF & NAIC Growth & 95 & Domestic & No \\
\hline GRR & Asia Tigers & $95-96,99$ & Foreign & Yes \\
\hline GSG & Global Small Cap & $95-99$ & Foreign & Yes \\
\hline GSP & Growth Fund of Spain & $94-98$ & Foreign & No \\
\hline GTF & AIM Eastern Europe & 94-97 & Foreign & No \\
\hline $\mathrm{HQH}$ & H\&Q Healthcare Investors & $93-99$ & Domestic & Yes \\
\hline IAF & First Australia & $94-99$ & Foreign & Yes \\
\hline $\mathrm{IBF}$ & First Iberian & $94-96$ & Foreign & No \\
\hline $\mathrm{IF}$ & Indonesia Fund & $95-98$ & Foreign & Yes \\
\hline IGF & India Growth & $96-98$ & Foreign & Yes \\
\hline IIF & Morgan Stanley India Investment & $97-99$ & Foreign & Yes \\
\hline IMF & Inefficient Market & $94-96$ & Domestic & No \\
\hline IRL & Irish Investment & 94-99 & Foreign & Yes \\
\hline ISL & First Israel & $97-99$ & Foreign & Yes \\
\hline ITA & Italy Fund & $94-99$ & Foreign & Yes \\
\hline JEQ & Japan Equity & $95-99$ & Foreign & Yes \\
\hline
\end{tabular}




\begin{tabular}{|c|c|c|c|c|}
\hline Fund Ticker & Fund Name & Period $^{1}$ & Type $^{2}$ & Existence $^{3}$ \\
\hline JGF & Jakarta Growth & $95-98$ & Foreign & No \\
\hline KF & Korea Fund & $94-99$ & Foreign & Yes \\
\hline KFV & Quest For Value Capital & $93-96$ & Domestic & No \\
\hline KIF & Korean Investment & $95-96$ & Foreign & Yes \\
\hline LAM & Latin America Investment & $95-96$ & Foreign & Yes \\
\hline LAQ & Latin America Equity & $95,97-99$ & Foreign & No \\
\hline LDF & Latin American Discovery & $95,97-98$ & Foreign & Yes \\
\hline MEF & Emerging Mexico & $94-96$ & Foreign & No \\
\hline MF & Malaysia Fund & $94-98$ & Foreign & Yes \\
\hline MFV & MFS Special Value & $95-96$ & Domestic & Yes \\
\hline MGC & Morgan Grenfell Smallcap & 93-99 & Domestic & Yes \\
\hline MSF & Morgan Stanley Emerging Market & $95-99$ & Foreign & Yes \\
\hline MXE & Mexico Equity \& Income & 94-99 & Foreign & Yes \\
\hline MXF & Mexico Fund & 94-99 & Foreign & Yes \\
\hline NAF & New Age Media Fund & $95-96$ & Domestic & No \\
\hline NBM & Nations Balanced Target Maturity & 96,98 & Domestic & Yes \\
\hline NEF & Scudder New Europe & $94-96$ & Foreign & No \\
\hline OST & Austria Fund & $94-96$ & Foreign & Yes \\
\hline PBS & Pilgrim Regional Bankshares & 93-96 & Domestic & No \\
\hline PEO & Petroleum \& Resources & $93-99$ & Domestic & Yes \\
\hline PGF & Portugal Fund & 94-98 & Foreign & Yes \\
\hline RIF & Cohen \& Steers Realty Income & $93-96$ & Domestic & No \\
\hline ROC & R.O.C.Taiwan & $96-98$ & Foreign & Yes \\
\hline RVT & Royce Value & $93-99$ & Domestic & Yes \\
\hline SAF & Scudder New Asia & 94-99 & Foreign & Yes \\
\hline SBF & Salomon Brothers & $93-99$ & Domestic & Yes \\
\hline SHF & Schroder Asian Growth & 98 & Foreign & Yes \\
\hline SGF & Singapore Fund & $94-98$ & Foreign & Yes \\
\hline SNF & Spain Fund & 94-99 & Foreign & Yes \\
\hline SOA & Southern Africa & $96-99$ & Foreign & Yes \\
\hline SOR & Source Capital & $93-99$ & Domestic & Yes \\
\hline STBF & Southeastern Thrift \& Bank & $93-99$ & Domestic & Yes \\
\hline SWZ & Swiss Helvetia & 94-99 & Foreign & Yes \\
\hline TDF & Templeton Dragon & $96-99$ & Foreign & Yes \\
\hline TEA & Templeton Emerging Market App. & $98-99$ & Foreign & Yes \\
\hline TGC & Templeton Global Utilities & 94-95 & Foreign & No \\
\hline TKF & Turkish Investment & $96-98$ & Foreign & Yes \\
\hline TTF & Thai Fund & $95-98$ & Foreign & Yes \\
\hline TWN & Taiwan Fund & $95-98$ & Foreign & Yes \\
\hline TY & Tri-Continental & $93,95-99$ & Domestic & Yes \\
\hline UKM & United Kingdom Fund & $94-98$ & Foreign & No \\
\hline USA & Liberty All-Star Equity & $93-99$ & Domestic & Yes \\
\hline VLU & Worldwide Value & $94-96$ & Foreign & No \\
\hline $\mathrm{ZF}$ & Zweig & 94-99 & Domestic & Yes \\
\hline ZSEV & Z-Seven & $94-96$ & Domestic & Yes \\
\hline ZTR & Zweig Total Return & $94-99$ & Domestic & Yes \\
\hline
\end{tabular}

1. Stock return basis (January-December on each year)

2. Domestic: Domestic Equity Fund, Foreign: Foreign (International) Equity Fund

3. As of December 31, 1999 